\title{
The Impact of Corporate Governance Perception Index (CGPI) on Price to Book Value with Corporate Social Responsibility (CSR) as Moderating Variable (Bank Listed on Indonesia Stock Exchange in 2016-2018)
}

\author{
Rizky Indriyani Siregar ${ }^{1}$, Junino Jahja ${ }^{2}$ \\ \{rizkyindriyanisiregar@gmail.com ${ }^{1}$,ninoj2@gmail.com ${ }^{2}$ \} \\ Department of Management, Faculty of Economics and Business, University of Indonesia, \\ Indonesia, Depok, $1624^{12}$

\begin{abstract}
Every company should implement Good Corporate Governance (GCG), hoping by implementing GCG the company will get value-added and achieve sustainability business. Besides that, it is important to see the return for the company if it implements GCG especially for the value of the firm. This paper is an empirical study to investigate the impact of the Corporate Governance Perception Index (CGPI) on a firm's value which is measured by using the Price to Book Value (PBV) ratio. Besides that, this study used the publication of Corporate Social Responsibility (CSR) as moderating variable to see whether CSR could make CGPI's effect stronger in impacting PBV, therefore this study used 2 research model where model 1 uses CGPI and CSR and addition CSR as moderating variable in model 2. The result of research model 1 shows that CGPI has a negative significant impact on PBV and CSR has a negative insignificant impact on PBV. Research model 2 shows that both CGPI and CSR have a negative insignificant impact on PBV while moderating variable has a positive insignificant impact on PBV. This study showed different results from the previous study.
\end{abstract}

Keyword: Corporate Governance, PBV, CSR, CGPI, firm's value

\section{Introduction}

Corporate Governance was first introduced by the Cadburry Committee in 1992 in the Cadburry Report, which is a set of rules governing relationships between shareholders, managers, creditors, the government, employees, and other internal and external stakeholders relating to their rights and obligations [25]. The Organization for Economic Cooperation and Development (OECD) defines corporate governance as a "system used to direct and control the company's business activities. Corporate governance regulates the distribution of duties, rights and obligations of those with an interest in the life of the company, including shareholders, the Board of Directors, managers, and all members of non-shareholder stakeholders ". The Indonesian Institute for Corporate Governance defines "Good Corporate Governance as a process and structure implemented in running a company with the main objective of increasing shareholder value in the long run while still taking into account the interests of other stakeholders. The main objective of corporate governance is to create a system of checks and balances to prevent misuse of company resources "[22]

Stakeholders and the general public can measure bank performance through financial statements by making bank financial ratios as indicators. But now, the implementation of Good 
Corporate Governance is also used by stakeholders and the public in assessing whether the Bank can maintain its sustainability well and in the long run. Banks that have been listed on the Indonesia Stock Exchange (IDX) generally have been consistent in publishing Good Corporate Governance reports every year.

Good Corporate Governance (GCG) in Indonesia itself began to be known in 1997 when Indonesia experienced an economic crisis. One of the adverse effects of the economic crisis is the number of companies that fell because they were unable to survive, including Indonesian banks which experienced a rush and resulted in a systemic effect on banks. The poor implementation of GCG is thought to be one of the main causes for this.

$\mathrm{CG}$ can be measured by using many indicators and parameters such as financial reporting compliance, composition of Directors and Commissioners, certification and so on which will ultimately determine the company's perception index or commonly referred to as the Corporate Governance Perception Index (CGPI). Corporate Social Responsibility (CSR) is also a form of $\mathrm{CG}$ in the form of a company's contribution to the economic development of society.

Ishii and Metrick [15] conducted research on companies that implemented good corporate governance and the results of the study showed that these companies had higher values, profits and sales growth that was also higher.

In the case of Indonesia itself, Matanari [18] conducted a study by examining the effect of corporate governance on the market performance of listed companies in the manufacturing industry listed on the IDX. The research shows that the application of corporate governance has a positive and significant effect on the issuer's market performance.

Based on this description, the author would like to see the effect of the implementation of corporate governance on the banking firm value listed on the IDX both conventional and Islamic banks in Indonesia.

The author chose the banking sector as the research sample because there is still a lack of research on the implementation of CG in Indonesia by using banking as the research sample. The research period is 3 years, namely 2016-2018. The selection of the research period was carried out based on the availability of company ranking data in the application of $\mathrm{CG}$ in Indonesia.

\section{Literature Review}

\subsection{Agency Theory}

Hendriksen and Van Breda [10] state that the underlying concept of agency theory arises from the expansion of one individual actor of the information economy into 2 individuals. One such individual becomes an agent for the other referred to as the principal. The agent makes a contract to perform certain tasks for the principal and the principal makes the contract to reward the agent. The Principal employs agents to carry out tasks for the benefit of the principal including the delegation of authority for decision making from the principal agency. Principal and agent must have the same goals so that in operating the company, the agent will support and fulfill all the commands given by the principal.

However, there is the possibility of a conflict of self-interest by the agent. With the granting of authority by the principal, there is a conflict that may arise between the principal and the agent. The appointed agent will utilize all available resources to maximize the company's profit even by having to sacrifice shareholders. The agent understands that his work will determine 
the returns to be paid by the principle to him so that sometimes the agent only focuses on achieving the company's profit. The conflict of interest that occurs is called an agency conflict.

\subsection{Corporate Governance}

The Organization for Economic Cooperation and Development (OECD) and the World Bank define Good Corporate Governance as the management of a solid and responsible management, in line with democracy and avoiding collusion of Corruption Nepotism (KKN) both politically and administratively, running budget discipline and creating legal and political creation framework

Tunggal [32] defines Corporate Governance as a system that regulates, manages and oversees the process of controlling businesses to raise the value of shares, as well as a form of attention to stakeholders, employees and surrounding communities. The Forum for Corporate Governance in Indonesia / FCGI defines Corporate Governance as a set of rules that establish relationships between management stakeholders, creditors, governments, employees and other internal and external stakeholders with respect to their rights and obligations, or in other words the system who direct and control the company.

Research on the influence of CG has been carried out outside Indonesia. Pillai and AlMalkawi [23] conducted a study of 349 finance and non-finance companies by using Tobin's Q and ROA as dependent variables to measure firm performance and Government Shareholding, Audit Type, Board Size, CSR and Leverage as independent variables. The results showed that all independent variables significantly influenced firm performance. Abdulhamid and Salim [1] conducted a similar study by making 13 Commercial Banks the object of research and the results showed that ROE, EPS, MPBV, DPR and MPS had a significant positive relationship to Market Price which was the dependent variable. While the RPS variable has a significant negative relationship to Market Price. Girish and Desai [11] conducted a study of 10 companies and the results of the study showed that Cash Flow from operational activities had a significant relationship to Market Price that was used as the dependent variable to measure firm value. Reverte [25] conducted research using 35 companies as research objects and the results of the study showed that CSR disclosure has an effect on stock prices both directly and indirectly.

Indonesia itself has an institution that measures the CG level of each industry, especially companies that have been listed on the Indonesia Stock Exchange. The measurement is in index size and is commonly referred to as the Corporate Governance Perception Index (CGPI).

\subsection{Price to Book Value}

In general, previous studies used Tobin's $Q$ ratio or stock price as a measure of value firm or firm performance. But in this research, I use Price to Book Value (PBV) as the dependent variable to measure the firm value. PBV has several advantages to be used as a measurement tool that can assess the value firm, namely:

a) Book value has a relatively stable intuitive measure that can be compared with market prices. Investors who lack confidence in the discounted cash flow method can use PBV as a comparison

b) Book value provides consistent accounting standards for all companies and PBV can be used to compare between the same companies as an indication of under or overvaluation

c) Companies with negative earnings, which cannot be valued using the price earning ratio can be evaluated using PBV. 
Based on the explanation above, the researcher wants to conduct a study to see whether CGPI is able to influence the PBV of a Bank registered in Indonesia. The research hypotheses are as follows:

H0: The Corporate Governance Perception Index has a positive effect on price to book value

$\mathrm{H} 1$ : Corporate Social Responsibility has a positive influence on price to book value $\mathrm{H} 2$ :

H2: Corporate Social Responsibility strengthens the influence of Business Operations and financial activities on price to book value.

\section{Method}

This study uses panel data with a study period of 3 years, namely 2016 to 2018 with a sample of 43 banks listed on the IDX. Data obtained through several sources, including:

1. Annual report of each bank that is the object of research

2. The official website of the Indonesia Stock Exchange www.idx.co.id

3. The Indonesian Institute for Corporate Governance

4. Reuter's official website www.reuter.com

The use of panel data in this study is expected to provide better results because it is a combination of cross section data and time series so that it becomes a pool of data so that it can reflect the relationships between variables more clearly.

This study uses PBV as the dependent variable, CGPI as an independent variable, 8 control variables namely operational activities, investment activities, funding activities, bank size, bank type, Return on Equity (ROE), Return on Assets (ROA) and Dividend Payout Ratio ( DPR) and Corporate Social Responsibility (CSR). CSR is a form of GCG where the company is not only focused on looking for profit but is also expected to contribute to the economic and social development of the community. For this reason, the use of CSR is chosen to see whether companies that publish CSR in their financial statements can affect the company's PBV and whether CSR disclosure is able to strengthen the CGPI relationship as an independent variable in influencing PBV as the dependent variable.

The value of a company in the market is influenced by several indicators. This study uses several variables that represent these indicators, such as the size of the bank that will be represented by the total assets of the bank. The total assets will later be processed into natural logarithms. Then the type of bank in this study refers to the concept of financial institutions run by banks, whether the bank is a conventional bank or Islamic bank. ROE and ROA are profitability ratios which show the extent of the bank's ability to generate returns on equity and assets owned. And the DPR is a ratio that shows how much banks can provide dividends to shareholders for the performance for a certain year.

The research model used is as follows: 


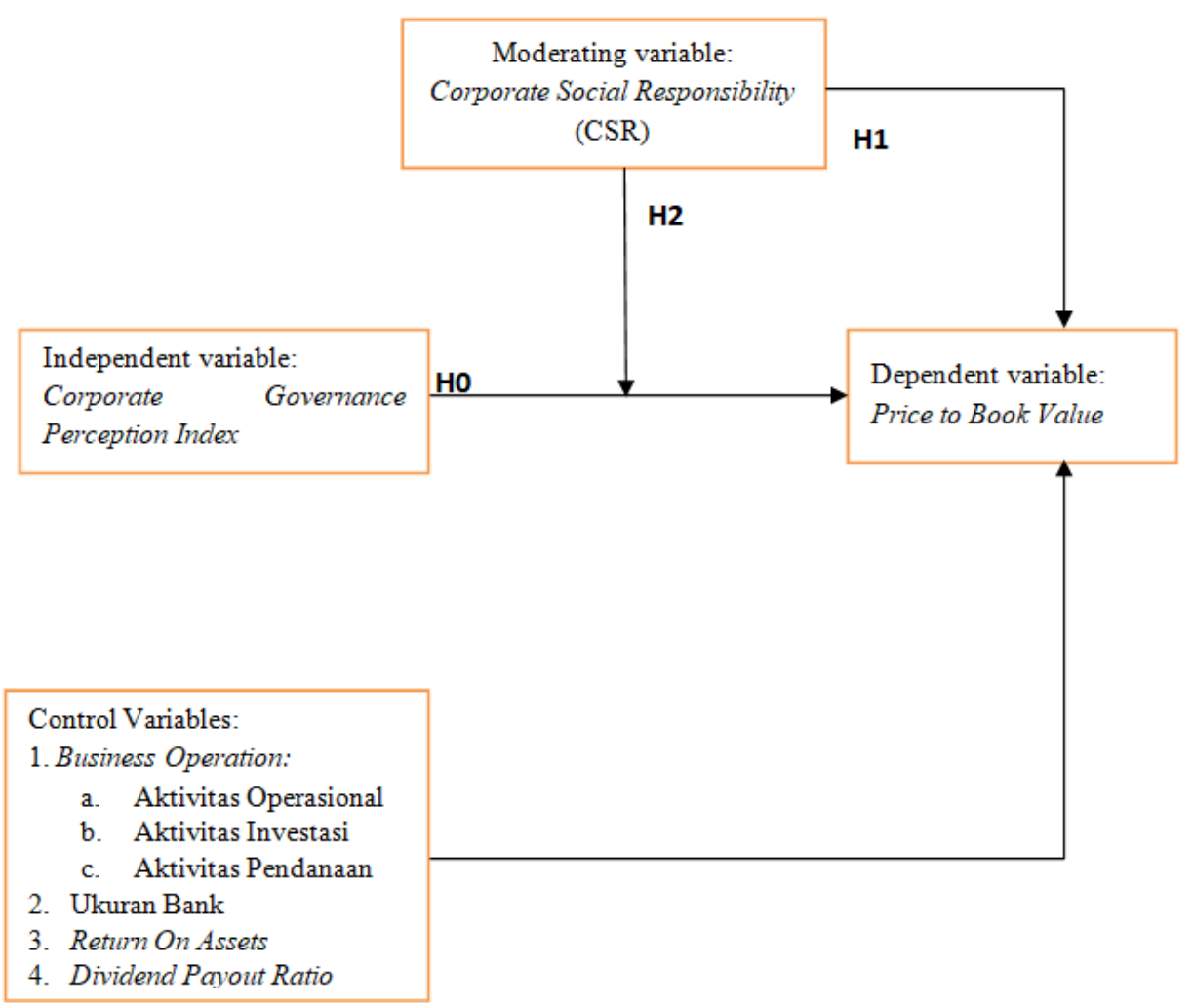

Fig.1. Research Framework

To test this hypothesis, 2 research models will be used wherein research model 1 is to test hypotheses 0 and 1 while research model 2 is used to test hypothesis 2 . The research model is as follows:

PBV $_{\text {it }}=\alpha_{0}+\alpha_{1}$ CGPI $_{\text {it }}+\alpha_{2}$ CSR $_{\text {it }}+\alpha_{3} A_{\text {At }}$ Operasional ${ }_{\text {it }}+\alpha_{4}$ Akt Investasi $i_{i t}+\alpha_{5} A k t$

Pendanaan $_{i t}+\alpha_{6}$ Size $_{i t}+\alpha_{7} J_{e n i s}$ Bank $_{i t}+\alpha_{8}$ ROE $_{i t}+\alpha_{9}$ ROA $_{i t}+\alpha_{10}$ DPR $_{\text {it }}$

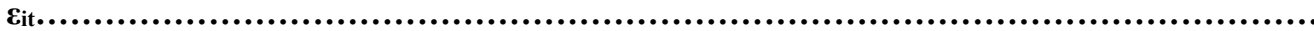

\section{...............Model 1}

\section{Information:}

PBV: Price to Book Value

CGPI: Corporate Governance Perception Index

CSR: Corporate Social Responsibility

Operational Act: Business Operation in terms of operational activities

Investment Act: Business Operation in terms of investment activities

Funding Act: Business Operation in terms of funding activities

Size: Bank size using the natural logarithm of total assets

Bank Types: Types of banks which are divided into 2 namely conventional banks and Islamic banks

ROE: Return on Equity

ROA: Return on Assets

DPR: Dividend Payout Ratio 
cit: Error

To test hypothesis 2 , the research model used is as follows:

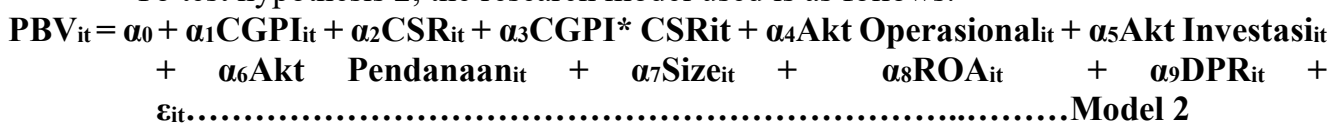

CGPI * CSR: Interaction between the Corporate Governance Perception Index and Corporate Social Responsibility

The definition of other variables is the same as the definition of variables in Model 1 Researchers use software in processing panel research data. The analysis used multiple regression analysis (Multiple Regression Analysis).

\section{Result And Discussion}

\subsection{Descriptive Statistics Analysis}

Descriptive analysis is used to provide an overview of the characteristics of the distribution of the data used. The table below shows descriptive statistics of all variables used in the study.

Table 1. Descriptive test result

\begin{tabular}{ccccccc}
\hline & $\mathbf{N}$ & Mean & Median & Max & Min & Std. Deviasi \\
\hline PBV & 129 & 0,267 & 0,220 & 1,530 & $-1,510$ & 0,626 \\
CGPI & 129 & 1,441 & 1,000 & 4,000 & 1,000 & 1,067 \\
CSR & 129 & 1,302 & 1,000 & 2,000 & 1,000 & 0,461 \\
OPERATIONAL & 129 & $-5,401$ & 4,760 & 108,540 & $-236,910$ & 51,952 \\
INVESTMENT & 129 & $-7,703$ & $-3,910$ & 112,480 & $-146,110$ & 32,537 \\
FINANCING & 129 & 12,411 & 2,660 & 128,070 & $-42,450$ & 27,462 \\
ASSETS & 129 & 17,001 & 17,010 & 20,980 & 11,160 & 2,146 \\
ROA & 129 & 0,994 & 1,480 & 12,400 & $-11,150$ & 3,071 \\
DPR & 129 & 13,502 & 0.000 & 76,400 & 0,000 & 18,995 \\
\hline
\end{tabular}

Keterangan: PBV = Price to Book Value; CGPI = Corporate Governance Perception Index; CSR = Corporate Social Responsibility; Operational = Operational activity; Investment $=$ Investment activity Financing $=$ Financing activity; Assets $=$ Total Asset; ROA = Return on Asset; DPR = Dividend Payout Ratio

*signifikansi $\alpha=0,005$

\subsection{Correlation Pearson Test}

Fraenkel and Wallen [9] stated that the correlation test in a study was conducted to see the relationship and the level of relationship between two or more variables without any effort to influence these variables so that variable manipulation did not occur. The correlation coefficient is measured using a range of values between -1 ; 0 ; and +1 . Correlation value of -1 means that the two variables have a perfect negative relationship. Correlation with a value of 0 means that the two variables do not have a relationship with each other while a correlation that has a value of +1 means that the two variables have a perfect positive relationship.

Autocorrelation test results for the research variables are presented in the table below: 
Table 2. Correlation Pearson test result

\begin{tabular}{cccccccccc}
\hline & PBV & CGPI & CSR & OPERS & INV & FIN & ASSET & ROA & DPR \\
\hline PBV & 1.00 & & & & & & & & \\
CGPI & 0,17 & 1.00 & & & & & & & \\
CSR & $-0,10$ & 0.29 & 1.00 & & & & & & \\
OPERS & 0.03 & 0.21 & 0.10 & 1.00 & & & & & \\
INV & 0,02 & -0.16 & -0.08 & -0.54 & 1.00 & & & & \\
FIN & -0.06 & -0.14 & -0.10 & -0.51 & 0.04 & 1.00 & & & \\
ASSET & $-0,09$ & 0.57 & 0.38 & 0.13 & -0.12 & -0.13 & 1.00 & & \\
ROA & -0.05 & 0.23 & 0,18 & 0.37 & $-0,19$ & $-0,32$ & 0.23 & 1.00 & \\
DPR & 0.10 & 0.27 & 0.26 & 0.17 & -0.07 & -0.17 & 0.31 & 0,30 & 1.00 \\
\hline
\end{tabular}

Based on the table above it can be seen that PBV as the dependent variable of research has a fairly variable relationship with the independent variables. The independent variable, CGPI, has a positive relationship with the dependent variable, PBV of 0.17 . This is an indication that the CGPI variable has a positive influence on the dependent variable, PBV. While the CSR variable has a negative correlation to the PBV dependent variable that is equal to -0.10 . This is an indication that the CSR variable does not have a positive influence on the dependent variable.

\subsection{Multicollinearity Test}

Ghozali [10] states that multicollinearity testing is performed with the aim of testing whether there is a correlation between the independent variables in the regression model used. A good regression model is a model that does not have multicollinearity problems. Multicollinearity testing can be done by looking at the value of the Variance Inflation Factor (VIF) of each variable. Variables are said to be free from multicollinearity problems if they have a VIF value not greater than 10 .

The multicollinearity test results of the study are presented in the table below:

Table 3. Multicollinearity test result

\begin{tabular}{ll}
\hline Variabel & Centered VIF \\
\hline CGPI & 1,555 \\
CSR & 1,222 \\
OPERS & 2,267 \\
INV & 1,626 \\
FIN & 1,577 \\
ASSET & 1,660 \\
ROA & 1,300 \\
DPR & 1,224 \\
\hline
\end{tabular}

Based on these test results, it can be seen that all variables have a VIF value $<10$ so that the variables used in this study are free from multicollinearity problems.

\subsection{Analysis of Regression Results}




\section{Model 1}

Based on the Chow test results obtained a probability value of 0.265 and the probability value for the Hausman test is 0.014 . This shows model 1 is more suitable for using the random effect method.

Table 4. Regression model 1 result

\begin{tabular}{|c|c|c|c|}
\hline \multicolumn{4}{|c|}{$\begin{array}{l}\text { PBV }_{\text {it }}=\alpha_{0}+\alpha_{1} \text { CGPI }_{\text {it }}+\alpha_{2} \text { CSR }_{\text {it }}+\alpha_{3} \text { Akt Operasional } \\
\text { Investasit }_{i t}+\alpha_{4} \text { Akt } \\
\varepsilon_{\text {it }}\end{array}$} \\
\hline Variabel & Prediksi & Koefisien & Prob. \\
\hline $\mathrm{C}$ & - & 2,768 & 0,230 \\
\hline CGPI & - & 0,283 & 0,018 \\
\hline CSR & - & 0,122 & 0,398 \\
\hline OPERS & + & 0,000 & 0,811 \\
\hline INV & + & 0,000 & 0,586 \\
\hline FIN & - & 0,001 & 0,317 \\
\hline ASSET & + & 0,216 & 0,112 \\
\hline $\mathrm{ROA}$ & - & 0,032 & 0,045 \\
\hline DPR & - & 0,001 & 0,533 \\
\hline Adjusted R-squared & \multicolumn{3}{|c|}{0,792} \\
\hline Prob (F-statistic) & \multicolumn{3}{|c|}{0,000} \\
\hline \multicolumn{4}{|c|}{$\begin{array}{l}\text { Keterangan: PBV }=\text { Price to Book Value; CGPI }=\text { Corporate } \\
\text { Governance Perception Index; CSR = Corporate Social } \\
\text { Responsibility; Operational = Aktivitas Operasional dari Business } \\
\text { Operation; Investment = Aktivitas Investasi dari Business } \\
\text { Operation; Financing = Aktivitas Financing dari Business } \\
\text { Operation; Assets = Total Aset; ROA = Return on Asset; DPR = } \\
\text { Dividend Payout Ratio } \\
\text { *signifikansi } \alpha=0,005\end{array}$} \\
\hline
\end{tabular}

By applying the random effect method the regression results are obtained as follows:

a. The Effect of Corporate Governance Perception Index on Price to Book Value

Based on the results of the model 1 regression in the table above, an adjusted R-squared value of 0.792 is obtained. This value shows that $79.2 \%$ of PBV at the Bank is influenced by CGPI, CSR, Operational, Financing, Asset, ROA and DPR variables. The remaining $20.8 \%$ is influenced by other variables not examined in this study.

The CGPI variable has a coefficient of -0.282 with a probability of 0.018 . With a probability value $<\alpha, 0.005$, thus the first hypothesis stating that CGPI has a positive effect on PBV is rejected. Research conducted by Pillai and Malkawi [23] shows the results that some parameters included in Corporate Governance such as Government Shareholding have a significant influence on firm performance. This has similarities with the research conducted by the author but the authors use PBV as an indicator of firm's value, and the CGPI variable shows significant negative results in influencing PBV. Black, Jang and Kim [5] conducted a similar study using the Korea Corporate Governance Index (KCGI) to see its effect on the value of Tobin's $q$ companies listed on the Korean Stock Exchange and found the results that an increase in the KCGI value of a company could predict the increase in Tobin's q value.

b. The Effect of Corporate Social Responsibility on Price to Book Value 
The CSR variable has a coefficient of -0.122 with a probability value of 0.398 . With the probability value $>\alpha$, it can be concluded that the CSR variable has no significant effect on PBV. Thus, hypothesis 2 which suspects that CSR disclosure has a significant positive effect on PBV, is rejected. The results of this study are in line with research conducted by Carnevale, Mazzuca and Venturini on the topic of whether CSR disclosure affects firm's market value as measured by stock price. The results of the study indicate that CSR disclosure does not have a significant correlation to stock prices.

But this is not in line with research previously conducted by Pillai and Malkawi [23] which shows the results that CSR has a significant influence on firm's performance. Harjoto and Laksmana [14] conducted a study to see whether CSR has an influence on firm's value as measured by Tobin's q value, and the results of the study show that CSR has an indirect positive relationship to firm's value.

In addition, the regression results show that the ROA variable as a control variable has a coefficient of -0.032 with a probability value of 0.045 .

\section{Model 2}

Based on the Chow test results obtained a probability value of 0.294 and the probability value for the Hausman test is 0.023 . This shows model 1 is more suitable for using the random effect method.

By applying the random effect method the regression results are obtained as follows:

Table 5. Regression model 2 result

\begin{tabular}{|c|c|c|c|}
\hline \multicolumn{4}{|c|}{ 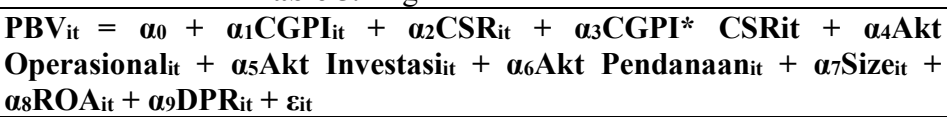 } \\
\hline Variabel & Prediksi & Koefisien & Prob. \\
\hline $\mathrm{C}$ & - & 2,454 & 0,297 \\
\hline CGPI & - & 0,469 & 0,105 \\
\hline CSR & - & 0,263 & 0,285 \\
\hline MODERASI & + & 0,093 & 0,477 \\
\hline OPERS & + & 0,000 & 0,816 \\
\hline INV & + & 0,000 & 0,693 \\
\hline FIN & - & 0,001 & 0,323 \\
\hline ASSET & + & 0,213 & 0,119 \\
\hline ROA & - & 0,032 & 0,048 \\
\hline DPR & - & 0,001 & 0,568 \\
\hline Adjusted R-squared & & 0,790 & \\
\hline Prob (F-statistic) & & $0,000 *$ & \\
\hline
\end{tabular}

Keterangan: $\mathbf{P B V}=$ Price to Book Value; $\mathbf{C G P I}=$ Corporate Governance Perception Index; CSR $=$ Corporate Social Responsibility; Moderasi $=$ CSR sebagai variabel moderasi; Operational = Aktivitas Operasional dari Business Operation; Investment $=$ Aktivitas Investasi dari Business Operation; Financing = Aktivitas Financing dari Business Operation; Assets $=$ Total Aset; ROA $=$ Return on Asset; DPR $=$ Dividend Payout Ratio

*signifikansi $\alpha=0,005$

a. The effect of the Corporate Governance Perception Index on Price to Book Value is moderated by Corporate Social Responsibility

Based on the results of regression model 2 in the table above, an adjusted R-squared value of 0.790 is obtained. This shows that $79.0 \%$ of the bank's PBV value is influenced by CGPI, 
CSR, Operational, Financing, Asset, ROA and DPR variables. The remaining $21.0 \%$ is influenced by other variables not examined in this study

The CGPI variable has a coefficient of -0.469 with a probability of 0.105 . The probability possessed by CGPI shows a value $>\alpha, 00.5$. This shows that the CGPI variable has a significant negative value in influencing PBV.

CSR variable has a coefficient of -0.263 with a probability value of 0.285 . With the probability value $>\alpha$, it can be concluded that the CSR variable has no significant effect on PBV.

The interaction between CGPI and CSR variables has a coefficient value of 0.093 with a probability value of 0.477 . The probability value $>\alpha, 0.005$ so that the interaction of CGPI and CSR variables or also known as moderating variables cannot strengthen the effect of CGPI on PBV or hypothesis 3 is rejected.

\section{Conclusion}

The results showed that CGPI had a significant negative effect on PBV value and CSR had a non-significant negative effect on PBV value. This is not in line with the findings of previous studies which stated that Corporate Governance has a significant positive effect on the value of firm. This is possible because each industry has its own characteristics so that the effect of CGPI on the value of firm in each industry can be different. The OECD sets several indicators in measuring the corporate governance of a company but it does not make a measurement that has the same size for each industry.

ID4D (Identifiaction for Development) World Bank in an article in 2019 stated that in fact, corporate governance impact depends on the company's life cycle and institutional characteristics of the country of origin of the company and the stock market where the company is registered.

This study also shows the results that when CSR is used as a moderating variable, the CGPI and the moderating variable do not have a significant effect on PBV. This shows that the disclosure of the company's CSR activities in the bank's Annual Report is not able to strengthen CGPI in strengthening the influence of CGPI on PBV.

Thus, it can be concluded that this study answers the research questions in chapter 1, where CGPI significantly affects negativity towards PBV and CSR disclosure in annual reports by banks is not able to strengthen CGPI in influencing PBV.

\section{Research Limitation}

Some limitations in this study include:

1. The sample of this study is limited to Banks listed on the IDX. This results in the possibility that the results of the study can only provide a picture of the effect of CGPI on PBV only in the banking sector.

2. This study does not discard outlier data due to the limited sample and observation time used so that bank financial data in certain conditions such as mergers are still used in research.

\section{References}


[1] Abdulhamid Almaaiteh, Wesam dan Ahmad Salim Alsaraireh (2019). Accounting Indicators and their Impact on Market Prices of Shares of Commercial Banks Listed on The Amman Stock Exchange for the Period 2006-2017. International Review of Management and Marketing, 2019, 9(4), 32-38

[2] Agoes, Sukrisno (2011). Auditing (Pemeriksaan Akuntan) oleh Kantor Akuntan Publik. Edisi 4. Jakarta, Salemba Empat

[3] Agnes, Sawir (2008). Analisis Kinerja Keuangan dan Perencanaan Keuangan. Jakarta, PT Gramedia Pustaka Utama

[4] Alijoyo, A dan S. Zaini (2004). Komisaris Independen: Penggerak Praktik GCG di Perusahaan. Indeks AZ. Jakarta

[5] Black, Bernard S., Hasung Jang dan Woochan Kim. (2006). Does Corporate Governance Predict Firm's Market Values? Evidence from Korea. Journal of Law, Economics, \& Organization, Vol. 22 No. 2

[6] Blair, M. M. (1995). Corporate 'ownership': a misleading word muddies the corporate governance debate. The Brookings Review

[7] Bromiley, P., Govekar, M and Marcus, A. (1988). On Using Event-study Methodology in Strategic Management Research. Technovation

[8] Donaldson, L. and Davis, J. H. (1991). Stewardship Theory or Agency Theory: CEO Governance and Shareholder Returns. Australian Journal of Management

[9] Fraenkel, J. dan Wallen, N. (2008). How to Design and Evaluate Research in Education. McGrawHill Higher Education. New York

[10] Ghozali, Imam. (2011). Aplikasi Analisis Multivariate dengan Program SPSS. Semarang, Badan Penerbit Universitas Dipenogoro

[11] Girish S dan Kavitha Desai. (2017). Impact of Cash Flow from Operating and Financial Activities Information on Share Price: Empirical Evidence from Nifty Pharma Index Companies, India. International Journal of Management Research \& Review, Vol. 7

[12] Gitman, Lawrence J dan Chad J. Zutter.(2012). Principles of Managerial Finance $13^{\text {th }}$ edition. Boston, Pearson Education Limited

[13] Gosal, Pangemanan, Tielung. (2018). The Influence of Good Corporate Governance on Firm Valu: Empirical Study of Companies Listed in IDX30 Index Within 2013-2017. Jurnal EMBA Vol. 6 No. 4 September 2018

[14] Gul, Rashid, Muhammad. (2018). The Impact of Corporate Governance on Firm Value: The Case of Small, Medium, and Large Cap Firms.Pakistan Business Review Volume 20 Issue 2

[15] Harjoto, Maretno dan Indrarini Laksmana. (2018). The Impact of Corporate Social Responsibility on Risk Taking and Firm Value. Journal of Business Ethics

[16] Hendriksen, Eldon S. dan Michael F. Van Breda (2002).Teori Akuntansi. Buku 2. Batam, Interaksara

[17] Ishii, Gompers.P and Metrick, A. (2003). Corporate Governance and Equity Prices. Quarterly Journal of Economics. Vol. 118

[18] Jensen and Meckling, (1976). Theory of Firm: Managerial Behavior, Agency Cost, and Ownership Structure. Journal of Financial Economics

[19] Kaen, Fred. R. A. (2003). Blueprint for Corporate Governance: Strategy, and The Preservation of Shareholder Value. USA. AMACOM

[20] Kaihatu, Thomas S. (2006). Good Corporate Governance dan Penerapannya di Indonesia. Jurnal Manajemen dan Kewirausahaan, Vol. 8, No. 1

[21] Mallin, Christine A. (2013). Corporate Governance $4^{\text {th }}$ edition. Great Britain, Ashford Clour Press Ltd

[22] Matanari, Sich Jerry. (2013). Pengaruh Corporate Governance terhadap Kinerja Pasar Emiten Industri Manufaktur di Bursa Efek Indonesia. Tesis Magister Akuntansi, Universitas Indonesia

[23] Monk, Robert, A.G., and Minow, N. (2003). Corporate Governance $3^{\text {rd }}$ edition. Blackwell Publishing

[24] Pillai, Husam-Aldin Nizar Al-Malkawi. (2017). On the Relationship Between Corporate Governance and Firm Performance: Evidence from GCC Countries. Research in International Business and Finance 
[25] Rejeb, Wajdi Ben dan Mohamed Frioui (2012).The Impact of Good Corporate Governance Practices on Stakeholders Satisfaction in Tunisian Listed Companies. International Journal of Business and Management Studies, Vol. 4, No.

[26] Reverte, Carmelo. (2014). Corporate Social Responsibility Disclosure and Market Valuation: Evidence from Spanish Listed Firms. Journal of Economic Literature G32, M14

[27] Scott, William R (2000). Financial Accounting Theory $2^{\text {nd }}$ edition. Canada, Prestice Hall

[28] Shaw, John. C. (2003). Corporate Governance and Risk: A System Approach. New Jersey, John Wiley \& Sons, Inc

[29] Solomon, Jill. (2007). Corporate Governance and Accountability $2^{\text {nd }}$ edition. USA, John Wiley \& Sons, Inc

[30] Sudana, I Made (2011). Manajemen Keuangan Perusahaan Teori dan Praktik. Jakarta, Erlangga

[31] Sumarno, Widjaja, Subandriah. (2016). The Impact of Good Corporate Governance to Manufacturing Firm's Profitability and Firm's Value. Jurnal Ilmu Ekonomi Volume 5 (2)

[32] Tjager, I Nyoman., Alijoyo, F.A., Djemat, H.R., Soembodo, B. (2003). Corporate Governance: Tantangan dan Kesempatan Bagi Komunitas Bisnis Indonesia. Jakarta, PT. Prenhallindo

[33] Tunggal, Amin Wijaya. (2013). Internal Audit \& Corporate Governance. Jakarta, Harvarindo 